\title{
ANALISIS KEUNTUNGAN DAN KENDALA PENERAPAN KONSEP SISTEM PERTANIAN TERPADU (SPT) DI INDONESIA
}

\author{
Filya Hidayati $^{\left.{ }^{*}\right)}$, Yonariza $^{1)}$, Nofialdi ${ }^{1)}$, Dwi Yuzaria ${ }^{1)}$ \\ ${ }^{1}$ Pascasarjana Universitas Andalas Padang, Indonesia
}

${ }^{*}$ Corresponding author : nidya.fitri85@gmail.com

To cite this article:

Hidayati, F., Yonariza, Y., Nofialdi, N., \& Yuzaria, D. (2020). Analisis Keuntungan dan Kendala Penerapan Konsep Sistem Pertanian Terpadu (SPT) di Indonesia. JIA (Jurnal Ilmiah Agribisnis) : Jurnal Agribisnis dan IImu Sosial Ekonomi Pertanian, 5(3), 74 - 83. doi:http://dx.doi.org/10.37149/jia.v5i3.11688

Received: April 08, 2020; Accepted: June 13, 2020; Published: June 28, 2020

This research is to find the development of integrated agricultural systems implemented in several countries and in Indonesia and the constraints that occur in the implementation of integrated farming systems (IFS). IFS is a solution to a crisis situation where agriculture or livestock can no longer support all the economic, ecological, ecosystem, social, and technological aspects. This integrated farming system combines agriculture with livestock, fisheries, forestry, and tourism. Plants with livestock are interconnected and mutually beneficial and mutually supportive. This incorporation involves utilizing all existing resources in its entirety, to produce by-products in the form of waste utilization from agriculture and livestock (zero waste) and supported by technological developments to support it. The method uses integrated farming systems by looking for similarities, differences, views, and summarizes the results of previous research. This research covers literature studies on the development, implementation, and constraints that occur in integrated farming systems in several countries in the world, and Indonesia with various models of integrated farming systems are applied. Based on a literature study found that integrated farming systems can improve food security, farmer welfare, increase soil fertility, increase employment, create renewable technology, and the importance of government support to create opportunities for farmers in increasing their agricultural scale and more prosperous farmers in the future. In addition, there are also obstacles in IFS such as the absence of a correct understanding (farmers and facilitators), yield and productivity levels have not convinced farmers, the model is not in accordance with the ecosystem, has not utilized local potential, the existence of integrators have not been considered, yet the existence of comprehensive studies and agricultural development policies are not pro-farmers and lack of supporting technology.

Keywords: integrated farming system; constraints; farmer welfare; zero waste

\section{PENDAHULUAN}

Manusia mengembangkan sistem pertanian yang menggabungkan produksi tanaman pangan dengan peternakan 8 sampai 10 milenia yang lalu (Halstead P, 1996; Suryanti R, 2011). Sistem integrasi ini menyediakan beragam produk yang lebih besar ke keluarga petani daripada perusahaan sendiri dan menawarkan cara untuk memanfaatkan residu tanaman atau lahan non-pertanian untuk menghasilkan daging, susu, dan produk terkait, sekaligus menghasilkan pupuk kandang untuk memperbaiki kesuburan dan kualitas tanah yang dibudidayakan. Namun, selama 60 tahun terakhir, pertanian di banyak negara industri telah semakin terspesialisasi, mengakibatkan pemisahan usaha tanaman dan ternak (Romli M, T Basuki, \& J Hartono, 2012). Kikuhara K, (2008) mengembangkan model simulasi bioekonomi untuk mengevaluasi sistem integrasi tanaman susu dan hijauan di Jepang.

Penelitian terdahulu dilakukan di Nigeria mendefinisikan konsep tersebut sebagai jenis sistem pertanian campuran (Agbonlabor, M. U; Aromolaran, A. B. \& Aiboni, 2003) menggabungkan usaha tanaman dan ternak secara pelengkap dan/atau saling melengkapi dan saling tergantung. Membandingkan definisi (Radhammani, S; Balasubramanian, A.; Ramamoorthy, K. \& Geethalakshmi, 2003) menggambarkan SPT komponen sistem pertanian yang memperhitungkan konsep meminimalkan risiko, meningkatkan produksi dan keuntungan sambil memperbaiki pemanfaatan limbah organik dan residu tanaman. (Uvaneswaran \& Keerthana, 2015) menjelaskan bahwa 
pertanian terpadu atau produksi terpadu di India memakai pendekatan pertanian terintegrasi daripada pendekatan dilahan pertanian dengan menanam satu jenis tanaman saja (monokultur). Penjelasan ini merujuk pada sistem pertanian terintegrasi antara produksi ternak dengan tanaman pangan sehingga disebut dengan sistem bio terpadu.

Adnyana (2003); Pasandaran E., Djajanegara A., \& Kariyasa K (2005) menerangkan bahwa sistem integrasi tanaman-ternak (SITT) adalah merupakan sistem pertanian yang melibatkan komponen tanaman dengan terrnak pada suatu usaha tani disuatu areal atau wilayah. Tanaman dan ternak menjadikan penggunaan sumberdaya yang bervariasi, contohnya pada tanaman serta limbah dari tanaman dan juga pupuk organik dari kotoran hewan yang dihasilkan ternak. Model SITT, merupakan suatu solusi bagi petani karena petani dimudahkan dengan adanya ketersediaan pakan dengan menggunakan limbah tanaman, yaitu jerami jagung, jerami padi, limbah kacang-kacang serta limbah pertanian lainnya. Keunggulan penggunaan limbah adalah menaikkan "ketahanan pakan" apalagi pada saat datangnya musim kemarau, hal tersebut juga dapat menekan tenaga kerja dalam mencari hijauan seperti rumput, akhirnya ini merupakan solusi yang dipilih rumah tangga petani dalam menaikkan dan peningkatan jumlah pemeliharaan ternak.

Pertanian terpadu berhasil di Minneasota, hubungan sosial antara konsumen dan produsen perlu dikembangkan, sehingga menghasilkan kapital sosial masyarakat, masyarakat juga dapat memperoleh keuntungan untuk meningkatkan pertanian tanaman pangan / peternakan karena pertanian terpadu memiliki kapasitas untuk menghasilkan lebih banyak kalori makanan daripada peternakan tanaman pangan saja. Di Amerika Utara, Small, J.A., (1999) menjelaskan bahwa tempattempat di Amerika Utara telah menggunakan pertanian terpadu diantaranya adalah Wisconsin Integrated Cropping System (WICS) 1990, pertanian terpadu pada tahun 1992 di Nebraska, sistem pertanian terpadu secara biologi (BIFS), sedangakan pada tahun 1994 di California, Pusat Sistem Pertanian Lingkungan (1999) di North Carolina, Ley Farming System (LFS) pada tahun 1998 di North Dakota, sistem peternakan/peternakan terpadu di Texas (1999), sistem pakan ternak terpadu, tanaman dan ternak untuk dataran tinggi di North Dakota, peternakan petani Dudley (2002) di Illinois, Four State Ruminant Consosrtium (2003) di Montana, Dakota Selatan, Dakota Utara dan Wyoming, Alabama (2003) dan Kanada (2005).

Sedangkan konsep pertanian terpadu di Indonesia dengan mengkombinasikan ternak dan tanaman yang sebelumnya digunakan oleh petani bahkan pada awal petani mengetahui tentang pertanian. Manwan (1989) menerangkan pada tahun 1970an sistem usaha tani terpadu sudah mulai diperkenalkan, yang didasarkan pada banyaknya hasil yang sudah dikaji dan diteliti, yang diawali dengan adanya penelitian oleh Lembaga Pusat Penelitian Pertanian (LP3) di Bogor yang mengacu pada pola di IRRI (International Rice Research Institute). Sejak saat itu lahirlah berbagai beragam istilah diantaranya pola tanam (Cropping pattern), pola usahatani (cropping system) dan akhirnya lahirlah istilah sistem usahatani (farming system), serta yang paling terbaru muncul dengan istilah Crop Livestock System (CLS) yaitu sistem tanaman-ternak.

Rincian Sembilan Agenda Prioritas (Nawa Cita) Pemerintah Republik Indonesia, lahirlah agenda prioritas di bidang pertanian yaitu peningkatan agroindustri dan peningkatan kedaulatan pangan dengan berlandaskan Rencana Pembangunan Jangka Menengah Nasional (RPJMN) ketiga (2015-2019). Visi Renstra Direktorat Jenderal Peternakan dan Kesehatan Hewan (Ditjen PKH) tahun 2015-2019 yaitu terwujudnya kedaulatan dan keamanan pangan asal ternak dengan tujuan antara lain mengembangkan usaha peternakan yang terintegrasi dan meningkatkan pendapatan dan kesejahteraan petani peternak serta hal ini juga didukung oleh pemarintah melalui PP No.6 Tahun 2013 tentang pemberdayaan Peternak, khusus untuk usaha Integrasi usaha pertanian sawit dan sapi didukung oleh Permentan RI No105/Permentan/PD.300/8/2014, tentang integrasi usahatani dan ternak, dalam hal ini yaitu tanaman perkebunan sawit diintegrasikan dengan usaha budidaya ternak sapi potong.

Menurut Brunson, M.W \& Huntsinger (2008) menyatakan bahwa sektor ekonomi pertanian Indonesia memiliki posisi yang sangat krusial. Posisi inilah menyerap basis ekonomi rakyat pedesaan dan separuh rakyat Indonesia serta pekerja Indonesia. Selain itu, pendapat di atas diperkuat oleh data dari statistik Peternakan (2010) ikut serta berpartisipasi sejumlah 14,44\% pada Produk Domestik Bruto (PDB), begitu juga dengan kebutuhan primer meningkat sejalan dengan peningkatan penambahan penduduk dan pendapatan perkapita rakyat berasal dari pertanian (Badan Pusat Statistik, 2013).

Masa yang akan datang, khususnya Sumatera Barat sanggup mengintegrasikan usahatani terpadu pada suatu daerah sehingga memenuhi pembangunan nasional berbasis lingkungan dengan mengaplikasikan pendekatan agribisnis. Hal ini bertujuan untuk mengendalikan alih fungsi lahan karena penggunaan lahan yang dilakukan secara terus menerus, seperti pada periode 1980an sampai 1990an untuk komoditas perkebunan khususnya kelapa sawit mengalami peningkatan areal 
dengan percepatan sebanyak $11 \%$ per tahun, peningkatan juga terjadi pada luas areal dan dengan percepatan 9,4 persen per tahun. Peningkatan juga merambah pada penggunaan domestik dengan percepatan dengan 10 persen untuk komoditas perkebunan khususnya kelapa sawit dan 13 persen per tahun untuk luas areal. Hal ini berdampak pada penyusutan daya produksi lahan sehingga mengakibatkan penyusutan hasil produksi yang dibuat oleh petani produsen. Untuk itu dengan pengendalian alih fungsi lahan bisa keberhasilan lebih efektif dan efisien (Nurcholis. H \& G. Supangkat, 2011), diantaranya yaitu pendayagunaan produksi hasil samping pertanian untuk pakan ternak dan pendayagunaan kotoran ternak yang digunakan untuk pupuk pada tanaman dengan menggunakan pendekatan zero waste. Pendayagunaan produk hasil samping tanaman dan kotoran ternak yang selama ini terbuang merupakan suatu bentuk tindakan ekonomis, serta merupakan pilihan yang efisien dalam mensejahterakan kehidupan petani untuk usaha peningkatan pendapatan petani (Sutanto, 2002) serta dengan memanfaatkan seluruh sumberdaya pada bidang pertanian pertanian secara maksimal.

Salah satu faktor penghambat petani adalah sistem usahatani dan tanaman ternak karena banyak faktor-faktor lain dalam berusaha tani. Dalam persaingan berusahatani dan isu pembangunan yang mengalami peningkatan, maka sistem pertanian terintegrasi tanaman ternak terpadu merupakan salah satu solusi bagi petani untuk menekan biaya produksi usaha ternak dan pupuk sehingga dapat memperbaiki mutu dari lahan yang telah rusak dikarenakan akibat dari menggunakan pupuk buatan. Salah satu pola yang dapat diintegrasikan dalam berusahatani adalah sistem pertanian berkelanjutan dengan teknologi input luar rendah (Low External Input Sustainable Agriculture-LEISA) dan terdapat beberapa pola yang digunakan petani diantaranya yaitu Sistem Integrasi Tanaman Pangan-Ternak, Sistem Integrasi Sapi Kelapa Sawit (SISKA) atau Sapi-Sawit (SASA), Sistem Integrasi Sapi-Tebu (SATE). Sementara itu, terdapat sejumlah pola integrasi tanaman ternak lainnya, seperti ternak dan kakao.

Jayanthi, C. \& Vennila (2008) menyatakan bahwa sistem pertanian terpadu merupakan sistem pertanian dengan menggabungkan dua serta lebih pada bidang pertanian, dengan mengimplementasikan konsep yang menjadikan bahan bekas dibuat menjadi sesuatu yang lebih berguna (daur ulang biologis) sehingga terjalin ikatan output input antarkomoditi. Sistem ini juga merambah komponen ternak dalam sistem usahatani dan sistem tanaman ternak. Hasil penelitian terdahulu menunjukkan sistem ini menaikkan produksi tanaman pangan dan ekonomi pertanian (Hanson, J.D \& Franzluebbers, 2008; Hendrickson, J., Sassenrath, G.F., Archer, D., Hanson, J. \& Halloran, 2008; Lantinga, E.A., Oomen, G.J.M. \& Schiere, 2004; Russelle, M.P., Entz, M.H. \& Franzluebbers, 2007; dan Tanaka, D.L., Karn, J.F., Liebig, M.A., Kronberg, S.L. \& Hanson, 2005).

Ismail, I. A., \& Djajanegara, H, 1989) berpandangan bahwa petani memakai kotoran ternak untuk penggunaan pupuk organik pada tanamannya, selanjutnya menggunakan limbah dari pertanian yang digunakan untuk pakan ternak, limbah pertanian dan perkebunan diduga memiliki kandungan nutrisi. Hasil dari produk samping dan limbah tersebut, sebenarnya dapat dimanfaatkan untuk memberikan nilai tambah dari tanaman. Pengolahan limbah pertanian menjadi pakan ternak dapat berupa pengolahan mekanik, pengolahan fisik, pengolahan kimia dan pengolaha biologi. Sistem pertanian terintegrasi tanaman-ternak membutuhkan pengembangan untuk mengurangi biaya pakan serta usaha ternak dan mengurangi biaya pupuk untuk tanaman sehingga mengubah mutu lahan yang sudah hancur dikarenakan efek pemakaian pupuk buatan. Tulisan ini adalah tentang meninjau kembali konsep dan sejarah tentang perkembangan serta pelaksanaaan dalam sistem pertanian terpadu, kemudian menjelaskan tentang keuntungan serta kendala yang terjadi selama menjalankan sistem pertanian terpadu pada Negara-negara termasuk di Indonesia. Berdasarkan bahasan diatas penulis tertarik mengkaji tentang: Bagaimana sejarah perkembangan sistem pertanian terpadu (SPT) di sejumlah negara di dunia dan Indonesia dan Hambatan-hambatan apa yang ditemukan pada penerapan sistem pertanian terpadu (SPT) di Indonesia. Dari bahasan diatas didapatkan tujuan penelitian diantaranya riset ini akan mendeskripsikan sejarah perkembangan SPT di sejumlah negara di dunia dan Indonesia serta dampak positif dari pelaksanaan penerapan dari SPT dan riset ini mengeksplorasi hambatan-hambatan apa yang ditemukan dalam penerapan SPT di Indonesia serta bagaimana solusi terhadap pemecahan masalah dari kendala-kendala yang terjadi.

\section{MATERI DAN METODE}

Metode penelitian ini dilakukan dengan menggunakan studi kepustakaan yaitu menelaah pertumbuhan pada sistem pertanian terpadu melalui tulisan yang ada serta pada jurnal yang berhubungan dengan sistem pertanian terpadu. Metode penelitian dengan studi kepustakaan adalah analisa perkembangan sistem pertanian terpadu serta keuntungan dan kendala yang ada dalam melaksanakan sistem pertanian terpadu. Pengolahan jurnal yang dilkukan didapatkan data, 
sedangkan data yang digunakan adalah data sekunder. Data yang diolah merupakan data yang menjelaskan tentang konsep pertanian terpadu, keuntungan pelaksanaan pertanian terpadu serta kendala yang terjadi dalam melaksanakan pertanian terpadu. Kemudian sampailah pada solusi dari pemecahan masalah pertamnian terpadu berupa kendala. Data yang sudah dikumpulkan akan di validasi, kemudian dianalasis dan akhirnya dinarasikan dengan baik, sehingga inforasi yang dituangkan dapat ditangkap oleh pembaca. Analisis data dan informasi bersifat deskriptif. Data yang dianalisis menggunakan analasis deskriptif, analisis deskriptif yaitu analisis yang menjelaskan perkembangan konsep serta keuntungan dan kendala dalam penerapan sistem pertanian terpadu.

\section{HASIL DAN PEMBAHASAN}

\section{Kebutuhan Sistem Pertanian Terpadu}

Munculnya Integrated Farming Systems (IFS) telah memungkinkan kita untuk mengembangkan sebuah kerangka kerja untuk model pengembangan alternatif untuk memperbaiki kelayakan operasi pertanian berukuran kecil dalam kaitannya dengan yang lebih besar. Sistem pertanian terpadu merupakan kata umum yang digunakan dalam menjelaskan pendekatan pertanian yang lebih terintegrasi dibandingkan dengan pendekatan budidaya pada lahan pertanian pada suatu areal atau tunggal (monokultur). Sistem pertanian yang menggabungkan produksi ternak dengan tanaman pangan atau dengan mengintegrasikan ikan, serta ternak, yang biasanya juga disebut dengan Integrated Biosystems. Integrasi biosistem merupakan serangkaian perusahaan yang saling terkait digunakan sehingga "limbah" dari satu komponen menjadi masukan bagi bagian lain dari sistem, yang mengurangi biaya dan meningkatkan produksi dan / atau pendapatan. SPT bekerja sebagai sistem sistem dan memastikan bahwa limbah dari satu bentuk pertanian menjadi sumber untuk bentuk lain. Karena memanfaatkan limbah sebagai sumber daya, kita tidak hanya menghilangkan limbah tapi juga memastikan peningkatan produktivitas secara keseluruhan untuk keseluruhan sistem pertanian.

Uvaneswaran \& Keerthana, (2015) menjelaskan bahwa pertanian terpadu diperlukan karena membuat hubungan yang kuat antara produksi tanaman pangan dengan kegiatan sekutunya dan menjadi daur ulang yang lebih baik untuk tujuan produktif dalam sistem terpadu terhadap perubahan teknik pertanian untuk produksi maksimum dalam pola tanam dan Memanfaatkan sumber daya dengan lebih baik untuk menjadikan usaha pertanian sebagai usaha yang memberi keuntungan dan kesempatan kerja yang mantap.

MacDonald, J.M., \& McBride, (2009) menjelaskan tentang spesialisasi dalam usahatani akan mengakibatkan turunnya harga pangan serta akan terjadi peningkatan aksesibilitas makanan yang dulu mahal seperti daging, juga menyebabkan biaya masyarakat dan lingkungan seperti polusi udara, kontaminasi saluran air dengan sedimen, serta pada daerah local juga terjadi masalah konsentrasi pupuk. Solusi alternatif dari spesialisasi yaitu sistem pertanian terpadu yaitu pengelolaan tanaman pangan dan hewan di satu peternakan. Penelitian tentang sistem pertanian terpadu menunjukkan bahwa pertanian terpadu tenyata dapat meningkatkan produksi tanaman pangan dan ekonomi pertanian (Lantinga, E.A., Oomen, G.J.M. \& Schiere, 2004; Tanaka, D.L., Karn, J.F., Liebig, M.A., Kronberg, S.L. \& Hanson, 2005; Russelle, M.P., Entz, M.H. \& Franzluebbers, 2007; Hanson, J.D., \& Franzluebbers, 2008; Hendrickson, J., Sassenrath, G.F., Archer, D., Hanson, J. \& Halloran, 2008)

Integrasi tanaman dan ternak jatuh dari praktik yang luas setelah tahun 1920an, dan ini telah menjadi seni yang hilang bagi banyak petani. Petani tanaman sering tidak memiliki pelatihan dalam bidang peternakan, dan pertanian terpadu memerlukan keahlian dengan tanaman dan ternak (Russelle, M.P., Entz, M.H. \& Franzluebbers, 2007). Secara khusus, petani muda sering tidak memiliki pengalaman, pelatihan, atau latar belakang bekerja dengan hewan. Di California, misalnya, usia rata-rata seorang peternak adalah 59 tahun. Petani yang akan diintegrasikan dengan latar belakang tanaman mungkin ditantang oleh perawatan hewan dan kesehatan (Hillimire, 2011). Di Guinea, Afrika, Sistem pertanian tanaman ternak terpadu menawarkan kesempatan untuk mempromosikan pertanian organik; dan membawa-bawa karbon dan nutrisi pada tahapan musim yaitu dari satu waktu ke waktu peralihan tanam berikutnya. Budidaya kacang polong dengan tujuan ganda seperti kacang tanah, kacang kedelai dan kacang tunggang untuk tujuan menyediakan pakan dan pakan ternak yang dapat dimakan, telah berkembang pesat di kalangan petani di padang rumput Guinea.

Agribisnis dibidang peternakan merupakan suatu yang sangat diminati sehingga bertumbuh dengan pesat saat lahan yang tersedia menjadi semakin terbatas. Sistem usahatani terpadu dituntut harus sejalan dengan peningkatan efisiensi dan efektivitas atas penggunaan lahan, modal, tenaga kerja serta terbatasnya faktor produksi tersebut. Sedangkan pada sektor peternakan sangat berdampak pada krisis ekonomi yang pertumbuhan yang menurun sebesar 1.92 persen, dan harus 
mewujudkan perbaikan serta penciptaan lapangan kerja untuk percepatan kesejahteraan petani melalui peningkatan pendapatan. Pada periode 1978-1986 pertumbuhan ekonomi pada sektor peternakan mengalami pertumbuhan ekonomi yang cukup tinggi \pm 7 persen per tahun. Sedangkan pada sektor pertanian khususnya tanaman pangan pada periode 1986-1997 mengalami penurunan dengan hanya tumbuh di bawah 2 persen, untuk sektor peternakan mengalami kenaikan hampir 6 persen pada periode yang sama.

(Ismeth Inounu dkk, 2008) menerangkan bahwa daya dukung alam dalam penanaman tanaman untuk hijauan yang diperuntukkan sebagai sumber pakan untuk ternak merupakan permasalahan untuk peningkatkan jumlah populasi sapi sebagai pemenuhan konsumsi daging bagi kebutuhan masyarakat. Sementara itu produk samping pertanian dan agroindustri yang belum dimanfaatkan merupakan sebuah solusi pilihan alternatif yang dipergunakan sebagai bahan pakan ternak sapi. Sistem integrasi antara pertanian dan peternakan ini ternyata mampu meningkatkan efisiensi, diantaranya biaya tenaga kerja, menghemat penggunaan lahan serta dapat mengurangi biaya perawatan dan biaya pemupukan, mengurangi biaya investasi untuk pembangunan jalan serta pengadaan alat transportasi yang dapat meningkatkan kesejahteraan rumah tangga petani serta masyarakat di sekitarnya.

Sedangkan Russelle, M.P., Entz, M.H. \& Franzluebbers, (2007) menjelaskan tentang integrasi di bidang pertanian menjadi menarik dikarenakan: kekhawatiran terhadap degradasi sumber daya alam, profitabilitas, stabilitas pendapatan pertanian, keberlanjutan jangka panjang, peraturan yang semakin terkonsentrasi serta sulitnya operasional pemberian pakan hewan.

\section{Pelaksanaan Sistem Pertanian Terpadu dan Dampaknya}

Hasil penelitian (Uvaneswaran \& Keerthana, 2015) menjelaskan pertanian terpadu adalah pendekatan manajemen keseluruhan pengelolaan keseluruhan yang menggabungkan ekologi lingkungan yang beragam dan sehat dengan tuntutan ekonomi pertanian untuk memastikan pasokan makanan sehat dan terjangkau yang berkelanjutan karena konsep yang dinamis, pastilah relevan di pertanian mana pun, di negara manapun, dan harus selalu menerima perubahan dan kemajuan teknologi. Yang terpenting, pertanian terpadu adalah cara praktis untuk pertanian yang akan menguntungkan semua masyarakat, tidak hanya mereka yang mempraktikkannya. Sistem pertanian terpadu dapat menjadi solusi yang baik bagi pembangunan yaitu dari pertimbangan social, ekonomi serta ekologi untuk mewujudkan produksi pangan pertanian berbasis bisnis.

Dampak kebijakan dan investasi pertanian di Zimbabwe dan Afrika Selatan, sektor komersial dan petani kecil di dua negara menunjukkan perbedaan sumber daya, dukungan kebijakan, dan kondisi pasar yang berpotensi signifikan dan dengan demikian berdampak pada perubahan kebijakan dan investasi pada produktivitas pertanian. Tren pertumbuhan produksi dan produktivitas pertanian di Asia dan Pasifik dan menggambarkan suatu cara untuk mencapai ketahanan pangan yang berkelanjutan di wilayah ini. Mereka juga meneliti signifikansi relatif faktor-faktor ini dalam menentukan keberhasilan sebuah negara di bidang pertanian dan memberikan perhatian khusus pada peran investasi, baik dalam modal fisik dan manusia, dalam mempertahankan dan meningkatkan produktivitas pertanian. Dengan demikian, penelitian ini membuat perbandingan produktivitas pertanian dalam pertanian terpadu berdasarkan perbedaan input material, lahan, dan penggunaan tenaga kerja dengan mempertimbangkan aspek pengawasan dan waktu penggunaan input. Pada penelitian perbandingan usaha pertanian terpadu di Bangladesh dan negara lainnya dikemukakan oleh Uddin dan Takeya, (2006) menampilkan data sebagai berikut:

Tabel 1. Pernyataan komparatif pertanian terintegrasi yang dipraktikkan oleh berbagai negara tahun 2003 (Dolar USA) (Unit/ha)

\begin{tabular}{ccccccccc}
\hline & \multicolumn{2}{c}{$\begin{array}{c}\text { Duck-fish } \\
\text { Integrated Farming }\end{array}$} & $\begin{array}{c}\text { Poultry-fish } \\
\text { Intergrated } \\
\text { Farming }\end{array}$ & $\begin{array}{c}\text { Rice-fish } \\
\text { Integrated } \\
\text { Farming }\end{array}$ & \multicolumn{2}{c}{$\begin{array}{c}\text { Crop-livestock-fish } \\
\text { Homestead } \\
\text { Integrated Farming }\end{array}$} \\
\cline { 2 - 10 } & $\begin{array}{c}\text { Bangladesh } \\
\text { (BD) }\end{array}$ & India & BD & Thailand & BD & Philippines & BD & Vietnam \\
\hline $\begin{array}{c}\text { Gross Income, } \\
\text { GI }\end{array}$ & 3871 & 5132 & 3097 & 5566 & 768 & 1234 & 1496 & 1510 \\
\hline $\begin{array}{c}\text { Total Variable } \\
\text { Cost, TVC }\end{array}$ & 921 & 1711 & 855 & 2617 & 476 & 495 & 865 & 818 \\
\hline $\begin{array}{c}\text { Total Fixed } \\
\text { Cost, TFC }\end{array}$ & 45 & 85 & 50 & 211 & 104 & 282 & 77 & 86 \\
\hline Total Coat, TC & 966 & 1796 & 905 & 2828 & 580 & 777 & 942 & 904 \\
\hline
\end{tabular}


Tabel 1. Pernyataan komparatif pertanian terintegrasi yang dipraktikkan oleh berbagai negara tahun 2003 (Dolar USA) (Unit/ha)

\begin{tabular}{cccccccccc}
\hline & \multicolumn{2}{c}{$\begin{array}{c}\text { Duck-fish } \\
\text { Particulars }\end{array}$} & \multicolumn{2}{c}{\begin{tabular}{c} 
Integrated Farming \\
\cline { 2 - 9 }
\end{tabular}} & $\begin{array}{c}\text { Poultry-fish } \\
\text { Intergrated } \\
\text { Farming }\end{array}$ & $\begin{array}{c}\text { Rice-fish } \\
\text { Integrated } \\
\text { Farming }\end{array}$ & $\begin{array}{c}\text { Crop-livestock-fish } \\
\text { Homestead } \\
\text { Integrated Farming }\end{array}$ \\
\hline $\begin{array}{c}\text { Gross Margin, } \\
\text { GM }\end{array}$ & 2950 & 3421 & 1337 & 2949 & 292 & 748 & 631 & 692 \\
$\begin{array}{c}\text { (GM=Gl-TVC) } \\
\text { Nei Income, NI } \\
(\mathrm{NI}=\mathrm{Gl}-\mathrm{TC})\end{array}$ & 2905 & 3536 & 2192 & 2738 & 188 & 466 & 554 & 606 \\
\hline
\end{tabular}

Sumber: Uddin \& Takeya (2006)

Penelitian ini bertujuan untuk memajukan pertanian terpadu di Bangladesh dengan membangun perusahaan dan pengalaman di negara lain. Yang paling penting harus ditempatkan pada integrasi berbagai usaha pertanian. Hal ini akan meningkatkan produktivitas sumber daya yang tersedia dan memaksimalkan produksi pertanian dari jumlah lahan yang terbatas, sekaligus mengurangi polusi. Studi tersebut menunjukkan bahwa tingkat pengembalian yang lebih tinggi direalisasikan dari usaha peternakan itik terpadu di India, karena negara tersebut membesarkan breed bebek yang tinggi dan menebar kolam dalam waktu tertentu. Peternakan terpadu unggas dan ikan di Thailand mendapatkan hasil panen yang lebih besar apabila dibandingkan dengan Bangladesh. Dibandingkan dengan kembalinya Filipina, keuntungan bersih dari budidaya ikan padi lebih rendah di Bangladesh. Petani Vietnam mendapatkan hasil panen dan peternakan yang lebih tinggi sedangkan petani di Bangladesh menghasilkan jumlah yang lebih banyak dari ikan tambak dan berkebun homestead. Pertanian multi-usaha menghasilkan keuntungan lebih banyak daripada penanaman monokultur, meskipun integrasi perusahaan harus sesuai dengan kemampuan, sumber daya, dan kebutuhan petani tertentu; serta faktor sosial, ekonomi, dan lingkungan sekitar dia. Komposisi perusahaan lebih bervariasi antara suatau negara dengan negara lain, tergantung pada topografi lahan, iklim, preferensi individu, dan lain-lain. Penelitian ini harus dilihat sebagai titik awal yang dapat ditingkatkan melalui penggunaan metodologi terkait (Uddin \& Takeya, 2006).

Hillimire (2011) menjelaskan tentang pertanian terpadu dapat memperbaiki kualitas tanah dan mengurangi ketergantungan pada input eksternal, serta dapat membantu pengurangan dan pengelolaan terhadap hama dan peningkatkan keanekaragaman hayati liar pada lahan yang sangat penting secara kritis dan dapat meningkatkan penguatan ekonomi dibidang pertanian serta menghasilkan keamanan pangan bagi petani. Manfaat ekonomi dan lingkungan ditingkatkan saat rotasi tanaman dengan pakan ternak termasuk ternak yang terpecah. Petani sudah memiliki produksi sapi potong terpadu ke lahan pertanian di Great Plains untuk meningkatkan kemampuan keuntungan (McCaughey, 1999). Di Dakota Utara, misalnya, kekayaan bersih hampir $\$ 9.000$ lebih besar untuk peternakan dengan tanaman pangan dan sapi potong dibandingkan dengan tanaman pangan saja. Residu tanaman merepresentasikan sumber besar biomassa untuk pakan ruminansia atau energi di daerah di mana pemanfaatan tidak akan meningkatkan risiko degradasi lingkungan (Beauchamp, 1990). Sapi sapi telah mampu memanfaatkan hijauan dan residu tanaman, sedangkan betis telah diberi pakan selama preconditioning dan finishing. Sistem penggembalaan sepanjang tahun yang didasarkan pada pasak rumput legume dan residu tanaman jagung mengurangi kebutuhan akan jerami sebesar $900 \mathrm{~kg}$ bahan makanan kering (DM) saham induk sapi dan memberi keuntungan tambahan untuk mendukung bulan Agustus dan April. Biaya pakan ternak yang lebih rendah lebih banyak daripada kompensasi untuk tingkat keuntungan yang lebih rendah selama musim dingin, yang mengakibatkan biaya impas setidaknya $\$ 2,40 \mathrm{~kg} 21$ naik lebih rendah dari pada sistem pakan tradisional (Hanson, J.D., \& Franzluebbers, 2008).

Pada Provinsi Bali Sistem Pertanian Terpadu biasanya yang biasanya dikenal Simantri (sistem manajemen pertanian terintegrasi) merupakan model pembangunan pertanian pada Provinsi Bali. Program Simantri mendapatkan dukungan dari Pemerintah Daerah dalam perencanaan program pembangunan strategis daerah untuk "Bali Mandara" (Bali Aman Damai dan Sejahtera). Simantri merupakan integrasi vertikal dan horizontal kegiatan usahatani pada tingkat lokal, diawali dari proses perencanaan, perumusan kebijakan hingga akhirnya mengimplementasikan. Kelembagaan Simantri didukung melalui diversifikasi usahatani. Simantri sudah mulai direalisasikan dan dilaksanakan pada tahun 2008-2013 serta dilanjutkan 2013-2018. 
Penerapan integrasi lainnya adalah integrasi sawit-sapi misalnya integrasi ternak sapi yang dilaksanakan di perkebunan kelapa sawit akan memberikan keuntungan baik pada usaha ternak maupun usaha kelapa sawit. Salah satu perusahaan yang sudah melakukan integrasi tanaman dan ternaka adalah PT Agricinal Bengkulu yang biasa dikenal dengan Sistem Integrasi Sapi-Sawit Model Agricinal (SISKA). SISKA menjadikan ternak sapi digunakan sebagai penarik gerobak untuk mengangkut Tandan Buah Segar (TBS) dari lokasi pemanenan ke tempat penampungan sementara. $400 \mathrm{~kg}$ merupakan daya angkut satu ekor sapi dengan lahan pada permukaannya datar. Karena sebagaian tenaga yang digunakan adalah tenaga hewan atau sapi, menjadikan produktivitas panen meningkat serta berbanding lurus dengan peningkatan pendapatan serta kesejahteraan petani.

Pada akhirnya dalam pelaksanaan Integrated Farming Systems pada suatu usaha akan memperoleh keuntungan, keuntungan tersebut diantaranya yaitu: mendiversifikasikan sumber daya produksi, efisiensi penggunaan tenaga kerja, mengurangi terjadinya risiko usaha, efisiensi penggunaan input produksi, serta mengurangi ketergantungan energi kimia dan biologi serta membuat sistem ekologi lebih lestari dan tidak menimbulkan polusi sehingga ramah lingkungan, peningkatkan output, dan harus mammpu meningkatkan perkembangan ekonomi rumah tangga petani yang lebih berkelanjutan.

Pelaksanaan integrasi tanaman dan ternak (perkebunan sawit dan ternak sapi) dapat memberi keuntungan pada pertumbuhan ekonomi pada Kabupaten Langkat diantaranya penciptaan lapangan kerja sebanyak 114.447 orang atau $22.66 \%$ (12.16\% menjadi $34.82 \%)$ dari jumlah angkatan kerja di Kabupaten Langkat serta memberi pemasukan terhadap sektor peternakan senilai 177.81 milyar atau $3.85 \%$ dari $5.75 \%$ menjadi $9.6 \%$ dalam menyumbang PDRB sektor pertanian.

Penelitian lainnya di Bali, karakteristik petani simantri (sistem manajemen pertanian terintegrasi) serta pengaruh positif dari modal sosial terhadap produktivitas usahatani di Kabupaten Klungkung. Produktivitas usaha tani di Kabupaten Klungkung menyebabkan adanya pengaruh secara tidak langsung yang signifikan variabel karakteristik petani simantri dan modal sosial terhadap keberhasilan program Simantri.

\section{Kendala Pengembangan Sistem Pertanian Terintegrasi Tanaman-Ternak}

Prawiradiputra (2009) menerangkan bahwa sistem integrasi tanaman dan ternak di Indonesia ditemukan pengembangannya pada berbagai agroekosistem dengan tingkatan usaha yang juga bermacam-macam, diawali pada petani dengan kepemilikan lahan 0.5 ha, sampai kemuadian pada perkebunan kelapa sawit dengan luas yang mencapai ribuan hektar. Sementara itu belum dimanfaatkannya sumberdaya lahan dengan baik, serta belum optimalnya pemanfaatan modal serta tenaga kerja, kemudian kendala teknologi yang masih terjadi, serta minimnya informasi yang didapatkan petani dan kelembagaan yang mendukung usahatani petani.

Masalah lainnya di Indonesia adalah ketersedian lahan untuk usaha pertanian yang semakin terbatas yang terjadi pada rata-rata petani di Indonesia. Kepemilikan lahan yang kurang dari $0,5 \mathrm{Ha}$ pada keluarga petani (KK) semakin banyak akibat masalah alih fungsi lahan. Badan Pusat Statistik (2013) menerangkan bahwa rumah tangga petani mempunyai kepemilikan lahan 0.3-0.4 Ha. Sedangkan pada Propinsi Nusa Tenggara Barat (NTB) per rumah tangga petani (RTP) memiliki luas lahan yang paling sedikit agar bisa hidup dengan layak adalah $0.78 \mathrm{Ha}$. RTP perlu diarahkan agar memperoleh pendapatan layak dan berkelanjutan secara ekologis dan ekonomis akibat adanya masalah fragmentasi lahan (lahan pertanian yang semakin sempit). Akhirnya, perlunya mendapatkan hasil yang sesuai dengan keinginan bila perencanaan yang dilakukan oleh petani sangat bagus.

Masalah selanjutnya yang timbul sebelum pemanfaatan sistem Integrasi Kelapa Sawit-Sapi menurut Bangun, R (2010) adalah adanya petani yang hanya menghapkan serta menggantungkan keberlangsungan hidupnya hanya dari perkebunan kelapa sawit. Penyediaan sumber pakan ternak baik berupa hijauan makan ternak maupun dari limbah perkebunan kelapa sawit dalam jumlah yang sangat besar serta berkelanjutan yang mampu dihasilkan dari perkebunan sawit yang luas. Sementara itu adanya kebiasaan masyarakat yang akan menghasilkan efisiensi ekonomi apabila dalam perkebunan kelapa sawit tersebut juga dalam memelihara ternak besar seperti sapi.

Menurut Romli, M., T, Basuki, \& J, Hartono (2012) menerangkan bahwa daerah di Jawa Timur adanya sumberdaya yangbelum dimanfaatkan sama sekali yaitu limbah tanaman tebu. Agar limbah tebu yang dihasilkan dalam jumlah banyak pada waktu singkat disarankan agar limbah tersebut perlu diolah lebih lanjut untuk dapat diawetkan dan ditingkatkan kualitasnya agar bisa dimanfaatkan pada saat kekurangan pakan ternak (Purba, 2013). Selanjutnya adanya kendala dan permasalahan yang terjadi pada pemanfaatan bagas untuk pakan ternak diantaranya adalah sifatnya yang kamba (bulky), akibatnya memerlukan tingginya biaya produksi mulai biaya transportasi sampai dengan biaya penggudangan. Ditambah dengan permasalahan masih terdapatnya kandungan gula 
yang tersisa saat penggudangan bagas sehingga bagas dengan mudah terserang jamur dan serangga yang akhirnya bias mendatangkan kerugian pada petani.

Pasandaran E., Djajanegara A., \& Kariyasa K (2005) menerangkan tentang sistem pertanian terintegrasi tanaman dan ternak sedangkan ternak sapi masih merupakan usaha sambilan bagi sebagian besar petani sehingga pemeliharaannya pun masih bersifat tradisional yang terjadi pada agroekosistem sawah irigasi, tadah hujan maupun lahan kering. Kenyataan yang terjadi adalah penyumbang terbesar terhadap pendapatan rumah tangga petani dilahan kering dalam struktur pendapatan rumah tangga seperti petani. Artinya, peningkatkan pendapatan petani dan peningkatan kuantitas dan kualitas daging sapi nasional yang dilakukan dengan efisien, belum tentu berkontribusi dari pendapatan dari ternak besar yang dipelihara.

Usaha integrasi ternak sapi dan tanaman kakao didaerah Kabupaten Lima Puluh Kota mengalami kendala pada palatabiltas (daya suka) yang rendah karena memanfaatkan daun hasil pemangkasan tanaman kakao dan kulit biji kakao untuk pakan sapi simental dan turunannya (Suryanti R, 2011). Disamping itu, relatif sedikitnya jumlah dan kandungan gizinya lebih rendah dari rumput gajah yang dihasilkan dari limbah kakao yang dihasilkan per luasan tertentu. Nilai ekonomis dari limbah kakao dapat ditingkatkan, tetapi hal tersebut membutuhkan dekomposer serta jumlah limbah yang harus banyak agar pengolahan limbah menjadi pakan ternak menjadi lebih efisien.

Nurcholis. H \& G. Supangkat (2011) menjelaskan bahwa untuk mewujudkan pembangunan pertanian yang berkelanjutan maka sistem pertanian yang diterapkan adalah sistem pertanian terpadu, yang diharapkan mampu menghambat laju fragmentasi (alih fungsi) lahan, tetapi pengembangan sistem pertanian terpadu belum bias berkembanga secara optimal dan meluas pada petani dikarenakan terdapat beberapa hal masih menjadi permasalahan dalam pengembangan sistem pertanian terpadu. Kendala-kendala tersebut, antara lain: 1. Petani maupun fasilitator belum memahami konsep dari sistem pertanian terpadu secara benar; 2 . Petani belum yakin akan tingkat hasil dan produktivitas sistem pertanian; 3. Pengembangan model sistem pertanian terpadu yang belum sesuai dengan kondisi ekosistem; 4. Potensi lokal yang belum didasarkan pada integrasi vertikal dan horisontal; 5. Belum diperhatikannya keberadaan integrator dalam sistem pertanian terpadu; 6. Sistem Pertanian terpadu belum dikaji secara komprehensif dan integralistik; 7. Pengembangan sistem pertanian terpadu belum secara jelas didukung oleh kebijakan pembangunan pertanian belum mendukung.

\section{Bidang yang berkaitan dengan sistem pertanian terpadu}

Selain sistem pertanian terpadu, ada juga beberapa sistem yang perlu pengkajian lebih dalam, (Nurmala, Tati., 2012) menerangkan tentang adanya keterkaitan serta hubungan antara satu sistem dengan sistem lainnya yang terjadi pada sistem pertanian terpadu, ternyata juga terjadi pada sistem pertanian lain, diantaranya yaitu sistem pertanian organic dan sistem pertanian berkelanjutan:

1. Sistem pertanian organik

Pemakaian bahan kimia terhadap tanah dan tumbuhan yang berlebihan sangat dihindari pada sistem pertanian organik. Bahan alami yang digunakan dalam pengolahannya adalah pupuk, pupuk yang digunakan seperti pupuk kompos organik. Adanya berbagai manfaat yang terdapat dalam sistem pertanian organik, yaitu pada kegiatan pemupukan yang dilakukan pada tanaman akan menghasilkan tanaman yang bebas dari residu atau sisa-sisa pestisida dan bahan kimia. Produk tanaman jelas lebih sehat dan segar yang dihasilkan dari sistem organik. Kelestarian dan keseimbangan alam dapat dijaga dari tanaman yang dibudidayakan secara organik. Menurut (Sutanto, 2002) mendefinisikan konsep pertanian organik merupakan suatu sistem produksi pertanian yang berazaskan daur ulang secara hayati. Daur ulang hara dapat mampu memperbaiki status kesuburan dan struktur tanah melalui sarana limbah tanaman dan ternak serta limbah lainnya. Teknik pertanian organik merupakan teknik pertanian yang tidak menggunakan bahan kimia (non sintetik), tetapi dengan penggunaan bahan-bahan organik (Pracaya, 2002).

2. Sistem pertanian Berkelanjutan

Dunlap, R. E., \& Van Liere (1992) menjelaskan bahwa pertanian berkelanjutan adalah suatu defenisi tentang tantangan bagi produsen untuk mempertimbangkan dampak jangka panjang yang diawali dari budidaya, interaksi sistem usahatani, dan dinamika sistem pertanian. Dalam konsep ini konsumen didorong agar lebih terlibat dalam partisipan aktif pada sistem pangan. Pada konsep ekologis, pertanian berkelanjutan tanpa penggunaan masukan yang berlebih sangat berkaitan dengan usaha untuk memelihara sistem biologis agar dapat digunakan secara berkelanjutan dan dapat memberikan tingkat luaran yang sama. Kemudian pada tingkatan praktis, dalam konsep ini sangat menuntut pemahaman menyangkut dinamika hara dan energi, interaksi berbagai tanaman dan organisme lain dalam suatu agroekosistem, serta 
kesetimbangannya dengan keuntungan/pendapatan, dan kebutuhan konsumen serta kepentingan komunitas

\section{KESIMPULAN}

Masalah pertanian yang ada, hampir di seluruh dunia mencoba melaksakan metode sistem pertanian terpadu, yang pada pelaksanaannya berbeda-beda dalam pengintegrasian antara pertanian dan usaha lainnya, di antaranya ada yang melakasanakan pertanian dan perikanan, pertanian dan peternakan, perkebunan dan peternakan, pertanian dan usaha wisata, dan lainnya, dan pada intinya usaha tersebut memberikan hasil yang menguntungkan untuk kedua belah pihak berdasarkan hasil riset yang sudah dilakukan, yang mana terjadi peningkatan pendapatan petani, peningkatan pengetahuan petani, peningkatan kesuburan lahan, ekosistem yang diperbaiki secara bertahap dan manfaat lainnya. Banyaknya dampak positif yang diperoleh dari penerapan sistem tanaman ternak yang terintegrasi, ditemukan juga beberapa permasalahan berupa kendala-kendala pada penerapannya, diantaranya yaitu : 1. Petani maupun fasilitator belum memahami konsep dari sistem pertanian terpadu secara benar; 2 . Petani belum yakin akan tingkat hasil dan produktivitas sistem pertanian; 3. Pengembangan model sistem pertanian terpadu yang belum sesuai dengan kondisi ekosistem; 4. Potensi lokal yang belum didasarkan pada integrasi vertikal dan horisontal; 5 . Belum diperhatikannya keberadaan integrator dalam sistem pertanian terpadu; 6 . Sistem Pertanian terpadu belum dikaji secara komprehensif dan integralistik; 7 . Pengembangan sistem pertanian terpadu belum secara jelas didukung oleh kebijakan pembangunan pertanian belum mendukung; 8 . Kurangnya teknologi pendukung sistem pertanian terpadu yang dipahami oleh petani, walaupun pada kenyataannya memberikan pendapatan yang lebih.

\section{REFERENSI}

Adnyana, et al. (2003). Pengkajian dan Sintesis Kebijakan Pengembangan Peningkatan Produktivitas Padi dan Ternak (P3T) ke Depan. Laporan Teknis Pusat Penelitian Dan Pengembangan Tanaman Pangan. Litbang Pertanian. Bogor.

Agbonlabor, M. U.; Aromolaran, A. B. \& Aiboni, V. I. (2003). Sustainable soil management practices in small farms of Southern Nigeria: A poultry-food crop integrated farming approach. J. Sustain. Agr, 22, 51-62.

Badan Pusat Statistik. (2013). Statistik Indonesia 2013. In Katalog BPS. https://doi.org/10.1007/s13398-014-0173-7.2

Bangun, R. (2010). Analisis Sistem Integrasi Sapi - Kebun Kelapa Sa wit Dalam Meningkatan Pendapatan Petani di Kabupaten Rokan Hulu Provinsi Riau. Tesis. Universitas Andalas.

Beauchamp, E. . (1990). Animals and soil sustainability. J. Agric. En-Viron. Ethics 3(1):89-98.

Brunson, M.W., \& Huntsinger, L. (2008). Ranching as a conservation strategy: Can old ranchers save the new west. Rangeland Ecology \& Management, 61(137-147.).

Dunlap, R. E., \& Van Liere, K. D. (1992). The "new environmental paradigm": A proposed measuring instrument and preliminary results. Journal of Environmental Education, 9, 10-19.

Halstead P. (1996). Pastoralism or household herding? Problems of scale and specialization in early Greek animal husbandry. World Archaeol. 28(1):20-42.

Hanson, J.D., \& Franzluebbers, A. (2008). Principles of integrated agricultural systems. Renewable Agriculture and Food Systems, 23, 263-264.

Hendrickson, J., Sassenrath, G.F., Archer, D., Hanson, J. and Halloran, J. (2008). Interactions in integrated US agricultural systems: The past, present and future. Renewable Agriculture and Food Systems, 23, 314-324.

Hillimire, K. (2011). Integrated crop-livestock agriculture in the united states: a review. Journal of Suistainable Agriculture, 35, 376-393.

Ismail, I., \& A. Djajanegara, H, S. (1989). Farming Systems Research in Upland Transmigration Areas: Case in Batumarta. Proceeding of an International Workshop. Agency for Agricultural Research and Development. Indonesia.

Ismeth Inounu dkk. (2008). Konsep Pedoman Sistem Integrasi Sam Di Perkebunan Kelapa Sawit. Pusat Penelitian Dan Pengembangan Peternakan: Bogor.

Jayanthi, C. \& Vennila, C. (2008). Integrated farming systems and sustainability for livelihood security. National Symposium on New Paradigms in Agronomic Research. Pp., 281-284.

Kikuhara K, H. K. dan H. H. (2008). Development and evaluation of a simulation model for dairy cattle production systems integrated with forage crop production. Asian-Aust. J.Anim. Sci, 22, 5771. 
Lantinga, E.A., Oomen, G.J.M. \& Schiere, J. . (2004). Nitrogen efficiency in mixed farming systems. Journal of Crop Improvement, 12, 437-455.

MacDonald, J.M., \& McBride, W. D. (2009). The Transformation of U.S. livestock agriculture: Scale, efficiency, and risks. Economic Information Bulletin No. 43. Economic Research Service, United States Department of Agriculture.

Manwan. (1989). Farming sistems research in Indonesia: its evolution and future out look. In: Sukmana et al. (eds). Development in Procedures for farming System Research. Proceeding of an International Workshop. Agency for Agricultural Research and Development, Indonesia.

McCaughey, S. J. . \& W. P. (1999). Beef cattle management in Manitoba. Can. J. Anim. Sci., 79:539545.

Nurcholis. H \& G. Supangkat. (2011). Pengembangan Integrated Farming System Untuk Pengendalian Alih Fungsi Lahan Pertanian Bengkulu 7 Juli 2011. Prosiding Seminar Nasional Budidaya Pertanian, Urgensi Dan Strategi Pengendalian Alih Fungsi Lahan Pertanian, ISBN 978-6.

Nurmala, Tati., A. D. S. (2012). Pengantar Ilmu Pertanian. Penerbit Graha llmu.

Pasandaran E., Djajanegara A., \& Kariyasa K. (2005). Kerangka Konseptual Integrasi TanamanTernak Di Indonesia. Integrasi Tanaman-Ternak Di Indonesia. Badan Litbang Pertanian. Departemen Pertanian, Jakarta.

Pracaya. (2002). Bertanam Sayuran Organik diKebun, Pot dan Polybag. PT. Penebar Swadaya.

Prawiradiputra, B. R. (2009). Masih Adakah Peluang Pengembangan Integrasi Tanaman dengan Ternak di Indonesia. Wartazoa, 19 (3).

Purba, F. H. K. (2013). Potensi Ampas Tebu dalam Peluang Usaha dan Pemanfaatan Komersial. Http://Heropurba.Blogspot.Com/2013/03/Potensi-Ampas-Tebu-Dalam-Peluang-Usaha.Html. Diunduh 12 Februari 2017.

Radhammani, S., Balasubramanian, A., Ramamoorthy, K. \& Geethalakshmi, V. (2003). Sustainable Integrated Farming Systems For Dry Lands: A Review. Agricultural Reviews Bangladesh, 24, 204-210.

Romli M, T Basuki, \& J Hartono, (2012). Sistem Pertanian Terpadu Tebu-Ternak Mendukung Swasembada Gula dan Daging. Balitbang Kementerian Pertanian, Jakarta.

Russelle, M.P., Entz, M.H. \& Franzluebbers, A. . (2007). Reconsidering integrated Crop-livestock systems in North America. Agronomy Journal, 99, 325-334.

Small, J.A., \& W. P. M. (1999). Beef cattle management in Manitoba. Can. J. Anim. Sci., 79, 539545.

Suryanti R. (2011). Penerapan Integrasi Usaha Tanaman Ternak serta Kebutuhan Penyuluhan Pertanian (Kasus Integrasi Usaha Kakao dan Sapi di Kecamatan Harau, Kabupaten Lima Puluh Kota). Thesis, Pascasarjana, Universitas Andalas.

Sutanto, R. (2002). Pertanian organik: Menuju Pertanian Alternatif dan Berkelanjutan. Jakarta: Kanisius, ISBN 979-2.

Tanaka, D.L., Karn, J.F., Liebig, M.A., Kronberg, S.L. \& Hanson, J. D. (2005). An integrated approach to crop/livestock systems: Forage and grain production for swath grazing. Renewable Agriculture and Food Systems, 20, 223-231.

Uddin \& Takeya. (2006). Comparative Study On Integrated Farming In Bangladesh And Other Countries. Bangladesh J. Agric. Econs XXIX, 1 \&2, 81-92.

Uvaneswaran \& Keerthana. (2015). Integrated Farming System (IFS): A New Entrance for Entreprenuers. Pezzottaite Journals, 4(2), Issn 2279-0918. 